\title{
Nitric oxide-mediated neurotransmission is attenuated in the anococcygeus muscle from diabetic rats
}

\author{
K.J. Way, J.J. Reid \\ Department of Pharmacology, University of Melbourne, Victoria, Australia
}

\begin{abstract}
Summary The effect of STZ-induced diabetes of 8-weeks duration was examined on nitric oxide-mediated neurotransmission in the rat anococcygeus muscle. In the presence of noradrenergic blockade and raised tissue tone, relaxant responses to nerve stimulation $(0.5-5 \mathrm{~Hz}$, for $10 \mathrm{~s}$ ), sodium nitroprusside (5 and $10 \mathrm{nmol} / \mathrm{l})$ and nitric oxide ( 1 and $3 \mu \mathrm{mol} / \mathrm{l})$ were significantly reduced in anococcygeus muscles from diabetic rats compared to responses from control rats $(p<0.05)$. In contrast, relaxations to papaverine (3 and $10 \mu \mathrm{mol} / \mathrm{l}$ ) were not reduced in tissues from diabetic rats. The nitric oxide synthesis inhibitor NOLA $(100 \mu \mathrm{mol} / \mathrm{l})$ abolished relaxant responses to nerve stimulation but had no effect on responses to any of the relaxant agents used. Exposure to NOLA at $10 \mu \mathrm{mol} / 1$ reduced stimulation-induced relaxations; this reduction was significantly greater in tissues from the diabetic group than from the control group
\end{abstract}

$(p<0.05)$, probably as a consequence of the smaller relaxant responses in muscles from diabetic rats. Contractile responses to nerve stimulation $(1-10 \mathrm{~Hz}$, for $10 \mathrm{~s})$, but not noradrenaline $(0.03-30 \mu \mathrm{mol} / \mathrm{l})$, were significantly greater in anococcygeus muscles from diabetic rats than from control rats $(p<0.05)$. NOLA $(100 \mu \mathrm{mol} / \mathrm{l})$ significantly enhanced stimulation-induced contractions $(p<0.05)$, however the enhancement was significantly less in tissues from diabetic rats $(p<0.05)$. The results suggest that STZ-induced diabetes impairs smooth muscle reactivity to nitric oxide in the rat anococcygeus muscle. [Diabetologia (1994) 37: 232-237]

Key words Anococcygeus muscle (rat), diabetes, nitrergic nerves, nitric oxide, NOLA, NANC transmission, nonvascular smooth muscle, sodium nitroprusside, streptozotocin.
Neuropathy of the autonomic nervous system is a complication of diabetes mellitus which may contribute to alterations in cardiovascular, gastrointestinal and genitourinary function $[1,2]$. These alterations may be manifested through clinical problems including postural hypotension, diabetic diarrhoea, diabetic cystopathy and impotence. The STZ-treated rat, an estab-

Received: 29 June 1993

and in revised form: 14 September 1993

Corresponding author: Dr. J.J.Reid, Pharmacology Research Laboratories, Department of Medical Laboratory Science, Royal Melbourne Institute of Technology, Melbourne Victoria 3001, Australia

Abbreviations: STZ, Streptozotocin; NOLA, Na-nitro-L-arginine; NANC, nonadrenergic noncholinergic; ANOVA, analysis of variance. lished animal model of insulin-dependent diabetes mellitus, has been extensively used to study the occurrence of diabetic autonomic neuropathy. Neurochemical and histochemical techniques have revealed that changes occur in the intestinal myenteric innervation of STZ-induced diabetic rats, including degeneration of noradrenergic nerves, reduced transmitter levels in serotonergic nerves, and increased choline acetyl transferase activity in cholinergic nerves [3-6]. In addition, functional studies have demonstrated that abnormalities occur in cholinergic neuromuscular transmission in rat small intestine $[7,8]$, and in myogenic reactivity to neurotransmitters and autacoids in rat jejunum [9], bladder [10], vas deferens [11] and various vascular preparations [12].

The NANC inhibitory innervation of gastrointestinal tissue from STZ-treated rats has been investigated, with specific alterations to the purinergic [13] and pep- 


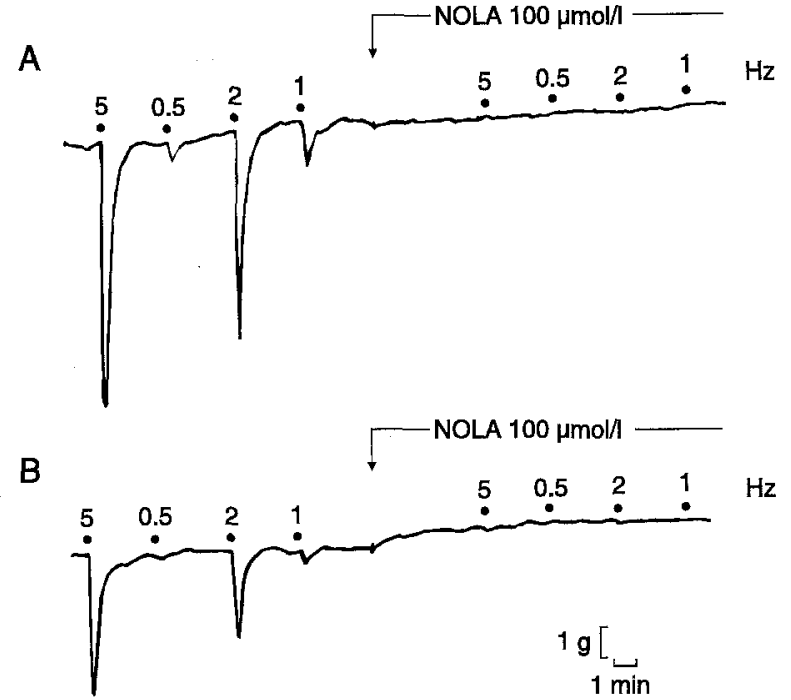

Fig.1A, B. Representative traces from experiments using anococcygeus muscle from control $(\mathbf{A})$ and diabetic $(\mathbf{B})$ rats, showing relaxant responses to increasing frequencies of field stimulation $(0 ; 0.5-5 \mathrm{~Hz}$, for $10 \mathrm{~s})$, before and after exposure to NOLA. Tissues were precontracted with guanethidine $(10-30 \mu \mathrm{mol} / 1)$ and clonidine $(0.01-0.05 \mu \mathrm{mol} / 1)$

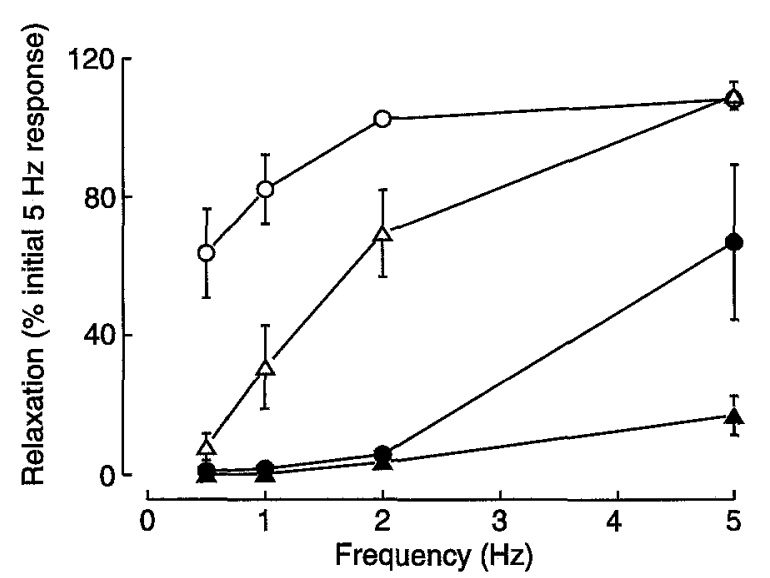

Fig. 2. Relaxant responses to field stimulation $(0.5-5 \mathrm{~Hz}$, for $10 \mathrm{~s})$ in anococcygeus muscles from control $(O)$ and diabetic $(\triangle)$ rats in the absence of NOLA, and from control $(\bullet)$ and diabetic $(\Delta)$ rats after a $10-\mathrm{min}$ exposure to NOLA $(10 \mu \mathrm{mol} / \mathrm{l})$. Values are mean \pm SEM from 3-6 experiments, expressed as percentages of the initial $5 \mathrm{~Hz}$ response obtained (control: $7.86 \pm 0.45 \mathrm{~g}, n=6$; diabetic: $4.30 \pm 0.62 \mathrm{~g}, n=12$ ). Tissues were precontracted with guanethidine $(10-30 \mu \mathrm{mol} / \mathrm{l})$ and clonidine $(0.01-0.05 \mu \mathrm{mol} / 1)$

tidergic [14] components reported. A role for nitric oxide or a nitric oxide-donating compound as a neurotransmitter in NANC nerves has been established in a number of gastrointestinal, genitourinary and vascular tissues, including rat anococcygeus, gastric fundus and ileum, rabbit urethra and corpus cavernosum, and dog cerebral and temporal artery [15]. Alterations to nitric oxide-mediated NANC (or nitrergic) [15] neurotransmission in the diabetic state have yet to be fully investigated, although numerous studies have demonstrated changes in endothelium-dependent relaxations to nitric oxide in arteries from diabetic animals [16-18].
Therefore the aim of the present study was to examine whether the diabetic state could alter nitrergic transmission using the STZ-treated rat; the anococcygeus muscle was chosen for use in the study because nitrergic innervation has been particularly well characterised in this tissue $[15,19]$.

\section{Materials and methods}

\section{Induction of diabetes}

Male Sprague-Dawley rats weighing $200-250 \mathrm{~g}$ from the inhouse breeding colony (Department of Pharmacology, University of Melbourne), were divided into two treatment groups. Diabetes was induced in one group by a single i.v. injection of STZ $(65 \mathrm{mg} / \mathrm{kg}$ ) given under light anaesthesia (pentobarbitone $40 \mathrm{mg} / \mathrm{kg}$ i.p.). The other control group was injected with citrate buffer vehicle alone $(20 \mathrm{mmol} / 1, \mathrm{pH} 4.5)$. In order to reduce the severity of the well-characterised hypoglycaemia following STZ treatment, all animals were given drinking water containing $2 \%$ sucrose for $48 \mathrm{~h}$ after injection; thereafter animals had free access to food and normal drinking water. STZ-treated rats were monitored for glycosuria (Tes-Tape urine sugar analysis paper; Eli Lilly, West Ryde, NSW, Australia), and blood samples were collected from all animals after decapitation for analysis of plasma glucose levels (Ames Glucometer II, Miles Laboratories Inc., Mulgrave, Vic., Australia).

\section{Tissue preparation}

Eight weeks after injection, rats were killed by stunning by a blow to the back of the head, followed by decapitation. The anococcygeus muscles were then isolated according to the method described by Gillespie [20]. An abdominal midline incision was made and the genital organs, bladder and urethra cleared, then the pelvis split. The exposed colon was cut at the pelvic brim and the pelvic portion pulled forward to reveal the two underlying muscles surrounded by connective tissue. A maximal length of each muscle was removed and mounted in a 5-ml organ bath under $1 \mathrm{~g}$ tension for isometric recording, using a Grass FTO3 C force displacement transducer (Grass Instruments Co., Quincy, Mass., USA) connected to a Rikadenki potentiometric recorder (Kogyo Co., Tokyo, Japan). Tissues were bathed in physiological salt solution of the following composition (mmol//; $\mathrm{pH} 7.4$ ): $\mathrm{NaCl} 118, \mathrm{KCl} 4.7, \mathrm{CaCl}_{2} 2.5, \mathrm{NaHCO}_{3} 25, \mathrm{KH}_{2} \mathrm{PO}_{4} 1.03, \mathrm{MgSO}_{4}$ $0.45, \mathrm{D}-(+)$-glucose 11.1 , disodium edetate 0.067 , and ascorbic acid 0.14 ; this was gassed constantly with $95 \% \mathrm{O}_{2} / 5 \% \mathrm{CO}_{2}$ and maintained at $37^{\circ} \mathrm{C}$.

Field stimulation was delivered from a Grass $\mathbf{8 8} 8$ stimulator (Grass Instruments $\mathrm{Co}$.) through two platinum wire electrodes, one on each side of the muscle, using square wave pulses of 0.8 $\mathrm{ms}$ duration and supramaximal voltage $(17 \mathrm{~V} / \mathrm{cm})$. An equilibration period of 20-40 min was permitted before experimental observations were made, and at the end of all experiments muscles were carefully blotted and then weighed.

\section{Relaxant and contractile responses}

Relaxant responses were assessed in the presence of guanethidine $(10-30 \mu \mathrm{mol} / \mathrm{l})$ and clonidine $(0.01-0.05 \mu \mathrm{mol} / \mathrm{l})$, to block noradrenergically mediated contractions and to raise tissue tone to approximately $8 \mathrm{~g}$. Relaxations were obtained to field stimulation $(0.5-5 \mathrm{~Hz}$, for $10 \mathrm{~s})$ at 3 -min intervals, or to sodium nitro- 
prusside $(5$ and $10 \mathrm{nmol} / \mathrm{l})$, nitric oxide $(1$ and $3 \mu \mathrm{mol} / 1)$ or papaverine $(3$ and $10 \mu \mathrm{mol} / \mathrm{l})$. In the absence of guanethidine and clonidine, contractile responses were obtained to field stimulation $(1-10 \mathrm{~Hz}$, for $10 \mathrm{~s})$ elicited at 2-min intervals, or to cumulative concentrations of noradrenaline $(0.03-30 \mu \mathrm{mol} / 1)$. Where indicated, relaxant or contractile responses were obtained before and after exposure to the nitric oxide synthase inhibitor, NOLA (10 and $100 \mu \mathrm{mol} / \mathrm{l}$ ); the appropriate time-control experiments were carried out in the absence of NOLA.

\section{Drugs and drug solutions}

Guanethidine sulphate, NOLA, (-)-noradrenaline bitartrate, papaverine hydrochloride, prazosin hydrochloride, sodium nitroprusside, STZ and tetrodotoxin, were all purchased from Sigma (St Louis, Mo., USA). Clonidine hydrochloride and pentobarbitone sodium were obtained from Boehringer Ingelheim (Artarmon, NSW, Australia). A saturated nitric oxide solution ( $2 \mathrm{mmol} / \mathrm{l}$ ) was prepared on the day of the experiment using a modification of the method described by Feelisch [21]; briefly, distilled water, initially deoxygenated by gassing with argon for $1 \mathrm{~h}$, was bubbled with nitric oxide gas for $30 \mathrm{~min}$. Both argon and nitric oxide gases were obtained from Commonwealth Industrial Gases (Melbourne, Vic., Australia).

\section{Statistical analyses}

Results are expressed as mean \pm SEM and $n$ indicates the number of animals tested. Differences between means were assessed using Student's $t$-test, or two-way ANOVA. Analyses were carried out using the software package, Complete Statistical System (CSS; Statsoft, Tulsa, Okla., USA). Probability levels less than 0.05 were considered significant.

\section{Results}

Eight weeks after injection, body weights of vehicletreated rats had increased from $247 \pm 5 \mathrm{~g}$ to $489 \pm 10 \mathrm{~g}$ $(n=27)$; this increase in weight was significantly greater than that for STZ-treated rats $(p<0.05$, unpaired Student's $t$-test) which changed from $231 \pm 5 \mathrm{~g}$ to $290 \pm 9 \mathrm{~g}(n=27)$. Plasma glucose levels in STZtreated rats 8 weeks after injection $(29.5 \pm 0.7 \mathrm{mmol} / \mathrm{l}$, $n=24)$ were significantly greater than levels in the vehicle-treated group $(6.7 \pm 0.2 \mathrm{mmol} / 1, n=27 ; p<0.05$, unpaired Student's $t$-test). Successful induction of diabetes was also confirmed by polydipsia, polyuria and glucosuria in STZ- but not vehicle-treated rats. Measurements of tissue weights revealed that anococcygeus muscles from diabetic animals $(10.0 \pm 0.5 \mathrm{mg}$, $n=37$ ) weighed significantly less than those obtained from control animals $(13.9 \pm 0.4 \mathrm{mg}, n=40 ; p<0.05$, unpaired Student's $t$-test).

\section{Relaxant responses}

In the presence of guanethidine $(10-30 \mu \mathrm{mol} / \mathrm{l})$ and clonidine $(0.01-0.05 \mu \mathrm{mol} / \mathrm{l})$, field stimulation $(0.5-5 \mathrm{~Hz}$, for $10 \mathrm{~s}$ ) of anococcygeus muscles from control and

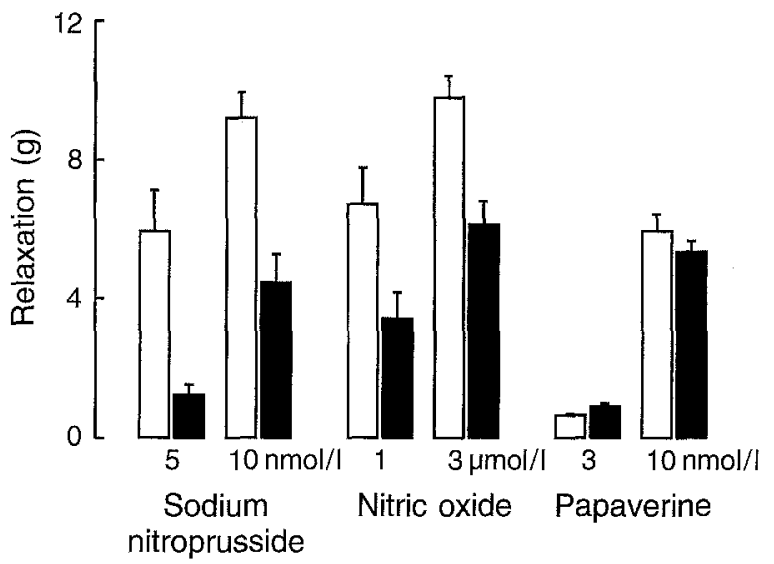

Fig.3. Relaxant responses to sodium nitroprusside, nitric oxide and papaverine in anococcygeus muscles from control $(\square)$ and diabetic ( $\boldsymbol{\square}$ ) rats. Values are mean \pm SEM from 7-11 experiments, expressed as absolute reductions in tension produced in tissues precontracted with guanethidine $(10-30 \mu \mathrm{mol} / 1)$ and clonidine $(0.01-0.05 \mu \mathrm{mol} / \mathrm{l})$

diabetic rats produced frequency-dependent relaxant responses (Fig. 1) which were abolished by tetrodotoxin $(1 \mu \mathrm{mol} / \mathrm{l}$; data not shown $)$. Relaxant responses to $0.5,1,2$ and $5 \mathrm{~Hz}$ stimulation in muscles from diabetic animals $(0.30 \pm 0.11 \mathrm{~g}, 1.01 \pm 0.29 \mathrm{~g}, 2.72 \pm 0.51 \mathrm{~g}$ and $4.19 \pm 0.51 \mathrm{~g}$, respectively; $n=18$ ) were significantly less ( $p<0.05$, two-way ANOVA) than those from control animals $(2.36 \pm 0.71 \mathrm{~g}, 4.10 \pm 0.67 \mathrm{~g}, 6.54 \pm 0.70 \mathrm{~g}$ and $7.13 \pm 0.63 \mathrm{~g}$, respectively; $n=13$ ). To account for differences in tissue weight and maximum responsiveness between the control and diabetic groups, data were normalised by expressing each response as a percentage of the initial $5 \mathrm{~Hz}$ response obtained in each experiment. When expressed in this manner, the frequency-response curve obtained using muscles from diabetic rats was still significantly less than that from control rats ( $p<0.05$, two-way ANOVA; Fig. 2$)$.

Exposure to NOLA $(100 \mu \mathrm{mol} / \mathrm{l}$, for $10 \mathrm{~min})$ increased the tone of the anococcygeus muscle from both diabetic and control rats by $0.66 \pm 0.08 \mathrm{~g}(n=8)$ and $0.90 \pm 0.12 \mathrm{~g}(n=8)$ respectively; the increases were significantly different from the corresponding values obtained in time-control experiments $(p<0.05$, unpaired Student's $t$-test), however the increase was not significantly different between the two groups ( $p>0.05$, unpaired Student's $t$-test). Furthermore, $10 \mu \mathrm{mol} / 1$ NOLA also produced slight increases in tone which were not significantly different in tissues from control $(0.33 \pm 0.15 \mathrm{~g}, n=4)$ and diabetic $(0.41 \pm$ $0.06 \mathrm{~g}, n=6$ ) animals ( $p>0.05$, unpaired Student's $t$-test). NOLA $(100 \mu \mathrm{mol} / 1)$ abolished stimulation-induced relaxations at all stimulation frequencies in both control and diabetic groups (Fig. 1), however in the presence of $10 \mu \mathrm{mol} / 1$ NOLA, relaxations were reduced in a frequency-dependent manner, the reductions being significantly greater in tissues from diabetic rats than in tissues from control rats $(p<0.05$, two-way ANOVA; Fig. 2). In corresponding time-control ex- 

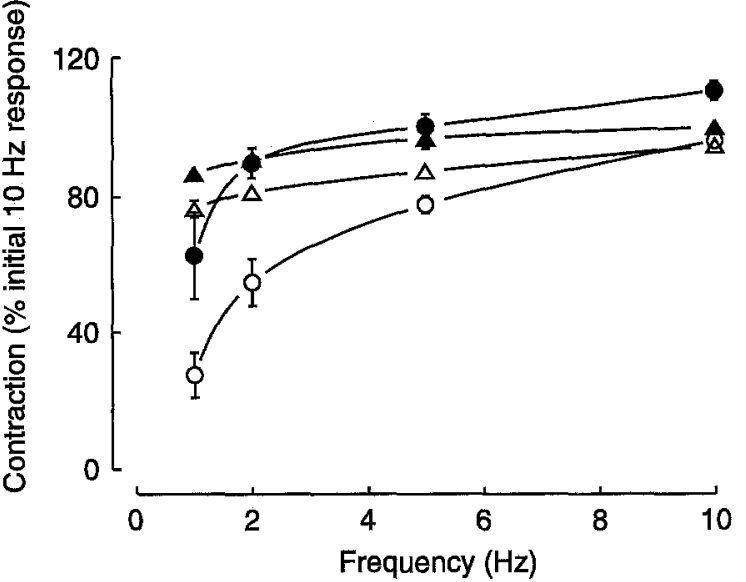

Fig.4. Contractile responses to field stimulation $(1-10 \mathrm{~Hz}$, for 10 s) in anococcygeus muscles from control $(O)$ and diabetic $(\Delta)$ rats in the absence of NOLA, and from control $(\bullet)$ and diabetic (A) rats after a $15-\mathrm{min}$ exposure to NOLA $(100 \mu \mathrm{mol} / \mathrm{l})$. Values are mean \pm SEM from 5-7 experiments, expressed as percentages of the initial $10 \mathrm{~Hz}$ response obtained (control: $7.09 \pm 0.51 \mathrm{~g}, n=11$; diabetic: $4.99 \pm 0.40 \mathrm{~g}, n=14$ )

A

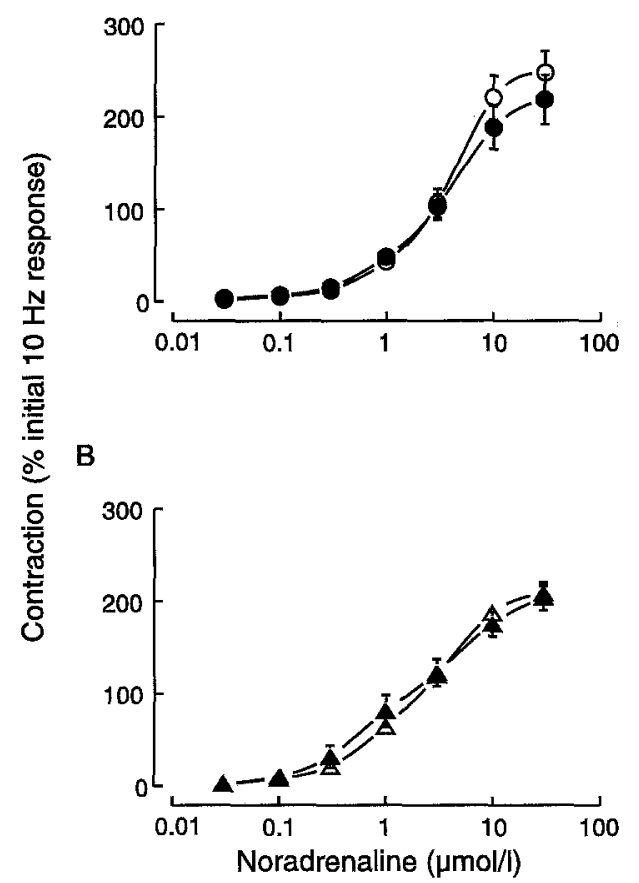

Fig.5A, B. Contractile responses to cumulative additions of noradrenaline in anococcygeus muscles taken from control (A) and diabetic $(\mathbf{B})$ rats. Contractions were obtained in the absence $(O, \Delta)$ or the presence $(\boldsymbol{\Delta}, \boldsymbol{\Delta})$ of NOLA $(100 \mu \mathrm{mol} / 1$, for $15 \mathrm{~min})$. Values are mean $\pm \mathrm{SEM}$ from six experiments, expressed as percentages of the initial $10 \mathrm{~Hz}$ response obtained (control: $6.48 \pm 0.83 \mathrm{~g}, n=12$; diabetic: $4.60 \pm 0.32 \mathrm{~g}, n=12$ )

periments, relaxant responses to nerve stimulation were consistent over the experimental time course ( $n=4$; data not shown).

Sodium nitroprusside ( 5 and $10 \mathrm{nmol} / \mathrm{l}$ ) produced relaxant responses which were significantly smaller in anococcygeus muscles from diabetic rats than from control rats ( $p<0.05$, unpaired Student's $t$-test; Fig. 3). Relaxations induced by nitric oxide were also significantly diminished in tissues from diabetic animals $(p<0.05$, unpaired Student's $t$-test; Fig. 3$)$. In contrast, papaverine ( 3 and $10 \mu \mathrm{mol} / \mathrm{l}$ ) caused relaxations of the muscle which were not impaired in tissues taken from diabetic rats; the response to $3 \mu \mathrm{mol} / 1$ papaverine was, in fact, slightly but significantly greater in muscles from diabetic rats ( $p<0.05$, unpaired Student's $t$-test; Fig. 3). NOLA $(100 \mu \mathrm{mol} / \mathrm{l})$ had no significant effect on the relaxant responses to sodium nitroprusside, nitric oxide or papaverine $(n=3-5, p>0.05$, paired Student's $t$-test; data not shown).

\section{Contractile responses}

Contractile responses to increasing frequencies of field stimulation $(1-10 \mathrm{~Hz}$, for $10 \mathrm{~s}$; expressed as a percentage of the initial $10 \mathrm{~Hz}$ response in order to normalise data within each experiment) were significantly greater in anococcygeus muscles from the diabetic group than from the control group ( $p<0.05$, two-way ANOVA; Fig. 4). Stimulation-induced contractions were abolished in the presence of prazosin $(0.1 \mu \mathrm{mol} / \mathrm{l}$; data not shown). A 15 -min exposure to $100 \mu \mathrm{mol} / 1$ NOLA had no effect on tissue resting tension (data not shown) but significantly enhanced contractions at all frequencies in both treatment groups ( $p<0.05$, two-way ANOVA; Fig. 4). The enhancement of responses was significantly less in tissues from diabetic rats than from control rats ( $p<0.05$, two-way ANOVA; Fig. 4 ). In corresponding time-control experiments, contractile responses were consistent throughout the experimental duration ( $n=5-7$, data not shown).

Concentration-dependent contractile responses to cumulative additions of noradrenaline (expressed as a percentage of the initial $10 \mathrm{~Hz}$ response) were not significantly different in tissues from control and diabetic animals ( $p>0.05$, two-way ANOVA; Fig. 5). Furthermore, NOLA $(100 \mu \mathrm{mol} / \mathrm{l})$ had no significant effect on noradrenaline-induced contractions elicited in tissues from either group ( $p>0.05$, two-way ANOVA; Fig. 5).

\section{Discussion}

In the present study stimulation-induced relaxations of the rat anococcygeus muscle were impaired at 8-weeks duration of diabetes, whether expressed in absolute terms or as a percent of the initial maximum response. The involvement of nitric oxide as the transmitter mediating relaxations was confirmed; NOLA $(100 \mu \mathrm{mol} / 1)$, an inhibitor of nitric oxide synthesis from L-arginine, abolished relaxant responses at all frequencies of stimulation tested, in agreement with $\mathrm{Li}$ and Rand [19]. At a lower concentration, NOLA $(10 \mu \mathrm{mol} / \mathrm{l})$ produced greater inhibition of relaxant responses in preparations from diabetic animals. This 
greater inhibition for the diabetic group was probably a consequence of the smaller relaxant responses which were obtained in muscles from diabetic rats. An increase in tone of precontracted muscles was also produced on addition of NOLA (10 and $100 \mu \mathrm{mol} / \mathrm{l})$. This is consistent with the previous findings of $\mathrm{Li}$ and $\mathrm{Rand}$ [19], and may be attributed to the inhibition of a small amount of tonically produced nitric oxide which would normally act to counterbalance the contractile response. As this increase in tone between the control and diabetic groups was not significantly different, there is no evidence from the present study for altered reactivity to tonically released nitric oxide in the diabetic state.

The reduction in stimulation-induced relaxant responses of the anococcygeus muscle in the diabetic state could suggest that alterations occur in the release of nitric oxide from nitrergic nerves or in the smooth muscle reactivity to nitric oxide, or both. In the present study, relaxations to the nitric oxide donor sodium nitroprusside and to nitric oxide itself were assessed to determine if the reduction in the relaxant response to nitric oxide released from nitrergic nerves, was due to decreased smooth muscle reactivity to nitric oxide. Relaxant responses to sodium nitroprusside and nitric oxide were reduced in muscles from diabetic rats, however relaxations to papaverine, which does not act through nitric oxide, were not reduced in preparations from diabetic animals. These findings suggest an impairment in smooth muscle reactivity to nitric oxide in anococcygeus muscle from diabetic rats. In addition, NOLA $(100 \mu \mathrm{mol} / 1)$ had no effect on relaxations to either sodium nitroprusside, nitric oxide or papaverine, thus supporting that the actions of NOLA are specific for the inhibition of nitric oxide synthesis in the rat anococcygeus muscle.

Several studies have reported changes in NANC inhibitory innervation induced by the diabetic state [14, $22,23]$. A recent publication [22] also using the rat anococcygeus muscle, but from STZ-treated rats of 4weeks duration, demonstrated no differences in the relaxant responses to NANC nerve stimulation between control and diabetic animals. Numerous factors could contribute to the difference in these findings from those of the present study; these include the strain of rat used (Wistar vs Sprague-Dawley), and the dose and route of STZ administration ( $75 \mathrm{mg} / \mathrm{kg}$ i. p. vs $65 \mathrm{mg} / \mathrm{kg}$ i.v.). The different duration of diabetes studied (4 weeks vs 8 weeks) might also play a role, although unpublished findings from our laboratory also reveal impaired nitric oxide-mediated relaxations to field stimulation in muscles from STZ-treated rats of 4weeks duration. Consistent with the results of the present study, an impairment in the stimulation-induced relaxant response of gastric fundus, which is mediated by nitric oxide and vasoactive intestinal polypeptide [24], has been demonstrated using STZ-treated rats of 12and 25-weeks duration [14]. Moreover, another study revealed an impairment of both the stimulation-in- duced and endothelium-dependent relaxant response of human corporal smooth muscle from impotent diabetic men [23]. As nitric oxide may act as the NANC neurotransmitter mediating the stimulation-induced relaxation of corporal smooth muscle $[25,26]$, the findings are also in accord with those of the present study.

The smooth muscle relaxant activity of nitric oxide and nitric oxide donors such as sodium nitroprusside, have been attributed to the activation of soluble guanylate cyclase, which in turn leads to a rise in intracellular cyclic GMP levels [27]. A diabetes-induced defect in this pathway could account for the decrease in smooth muscle reactivity to nitric oxide and nitric oxide donors observed in the present study. Another mechanism may involve an accelerated destruction of nitric oxide in the diabetic state. The quenching of nitric oxide by advanced glycation end-products has been recently implicated in the defective endothelium-dependent vasodilatation observed in experimental diabetes [28, 29], and may contribute to the reduction in nitric oxide reactivity observed in the present study.

It is recognised that nitric oxide released from NANC nerves can modulate noradrenergically mediated contractile responses of the rat anococcygeus muscle, as inhibitors of nitric oxide synthesis enhance contractions induced by field stimulation [19]. In the present study, noradrenergically mediated contractions to field stimulation in muscles from diabetic rats were greater than those obtained from control rats. Field stimulation of the muscle activates both noradrenergic and NANC nerves to elicit a contractile response which is partly counterbalanced by the NANC inhibitory transmitter; thus enhanced contractions of muscles from diabetic rats would arise if the opposing relaxant response mediated by nitric oxide was impaired. In addition, no differences in contractile responsiveness to cumulative doses of noradrenaline were observed between the two groups, indicating unaltered smooth muscle sensitivity to noradrenaline in the diabetic state. To further support the argument that the ability of nitric oxide to modulate noradrenergically mediated contractions is impaired in diabetes, the effect of nitric oxide synthesis inhibition on contractile responses to nerve stimulation was compared in muscles from control and diabetic animals. NOLA $(100 \mu \mathrm{mol} / \mathrm{l})$ enhanced stimulation- but not noradrenaline-induced contractile responses in tissues taken from either treatment group, in agreement with the previous findings of Li and Rand [19]. As the enhancing effect of NOLA was less in tissues from STZtreated rats than from control rats, the results are consistent with the findings that the ability of nitric oxide to relax smooth muscle is impaired in the anococcygeus muscle from diabetic rats.

In conclusion, relaxant responses to nitrergic nerve stimulation were attenuated in the anococcygeus muscle from 8-week STZ-treated rats. Consequently the ability of nitric oxide released from NANC nerves to modulate noradrenergically mediated contractions 
was also altered. The findings suggest that smooth muscle reactivity to nitric oxide may be impaired in diabetes as responses to sodium nitroprusside and nitric oxide were also attenuated. The impairment in nitrergic transmission and nitric oxide responsiveness is reversed in STZ-treated rats which have been given daily injections of insulin (Way and Reid, unpublished observations), confirming that the changes are related to diabetes. It remains to be established whether the release of nitric oxide from nitrergic nerves is also altered by the diabetic state in anococcygeus smooth muscle.

Acknowledgements. This work was supported by a Program Grant awarded to D.F. Story, J.J. Reid and M.J. Rand, from the National Health and Medical Research Council of Australia. Ms. K.J. Way is in receipt of an Australian Postgraduate Research Award.

\section{References}

1. Hosking DJ, Bennett T, Hampton JR (1978) Diabetic autonomic neuropathy. Diabetes 27: 1043-1054

2. Clarke BF, Ewing DJ, Campbell IW (1979) Diabetic autonomic neuropathy. Diabetologia 17: 195-212

3. Lincoln J, Bokor JT, Crowe R, Griffith SG, Haven AJ, Burnstock $G$ (1984) Myenteric plexus in streptozotocin-treated rats. Neurochemical and histochemical evidence for diabetic neuropathy in the gut. Gastroenterology 86: 654-661

4. Belai A, Lincoln J, Milner P, Crowe R, Loesch A, Burnstock $G$ (1985) Enteric nerves in diabetic rats: increase in vasoactive intestinal polypeptide but not substance P. Gastroenterology 89: 967-976

5. Belai A, Lincoln J, Burnstock G (1987) Lack of release of vasoactive intestinal polypeptide and calcitonin gene-related peptide during electrical stimulation of enteric nerves in streptozotocin-diabetic rats. Gastroenterology 93: 1034. 1040

6. Belai A, Lincoln J, Milner P, Burnstock G (1988) Progressive changes in adrenergic, serotonergic, and peptidergic nerves in proximal colon of streptozotocin-diabetic rats. Gastroenterology 95: 1234-1241

7. Nowak TV, Harrington B, Kalbfleisch JH, Amatruda JM (1986) Evidence for abnormal cholinergic neuromuscular transmission in diabetic rat small intestine. Gastroenterology 91: $124-132$

8. Nowak TV, Harrington B, Kalbfleisch J (1990) Adaptation of cholinergic enteric neuromuscular transmission in diabetic rat small intestine. Diabetes 39: 891-897

9. Mathison R, Davison JS (1988) Modified smooth muscle responses of jejunum in streptozotocin-diabetic rats. J Pharmacol Exp Ther 244: 1045-1050

10. Longhurst PA, Belis JA (1986) Abnormalities of rat bladder contractility in streptozotocin-induced diabetes mellitus. J Pharmacol Exp Ther 238: 773-777

11. Longhurst PA (1990) The effects of testosterone or insulin treatment on contractile responses of the rat vas deferens following castration or streptozotocin-induced diabetes mellitus. Gen Pharmacol 21: 427-434

12. MacLeod KM, McNeill JH (1985) The influence of chronic experimental diabetes on contractile responses of rat isolated blood vessels. Can J Physiol Pharmacol 63: 52-57
13. Belai A, Lefebvre RA, Burnstock G (1991) Motor activity and neurotransmitter release in the gastric fundus of streptozotocin-diabetic rats. Eur J Pharmacol 194: 225-234

14. D'Amato M, Currò D (1990) Non-adrenergic non-cholinergic inhibitory innervation of the gastric fundus in streptozotocin-diabetic rats. Acta Physiol Hung 75 [Suppl]: 77-78

15. Rand MJ (1992) Nitrergic transmission: nitric oxide as a mediator of non-adrenergic, non-cholinergic neuro-effector transmission. Clin Exp Pharmacol Physiol 19: 147-169

16. Oyama Y, Kawasaki H, Hattori Y, Kanno M (1986) Attenuation of endothelium-dependent relaxation in aorta from diabetic rats. Eur J Pharmacol 131: 75-78

17. Mayhan WG (1989) Impairment of endothelium-dependent dilatation of cerebral arterioles during diabetes mellitus. Am J Physiol 256: H621-H625

18. Taylor PD, McCarthy AL, Thomas CR, Poston L (1992) Endothelium-dependent relaxation and noradrenaline sensitivity in mesenteric resistance arteries of streptozotocin-induced diabetic rats. Br J Pharmacol 107: 393-399

19. Li CG, Rand MJ (1989) Evidence for a role of nitric oxide in the neurotransmitter system mediating relaxation of the rat anococcygeus muscle. Clin Exp Pharmacol Physiol 16: 933-938

20. Gillespie JS (1972) The rat anococcygeus muscle and its response to nerve stimulation and to some drugs. Br J Pharmacol 45: 404-416

21. Feelisch M (1991) The biochemical pathways of nitric oxide formation from nitrovasodilators: appropriate choice of exogenous NO donors and aspects of preparation and handling of aqueous NO solutions. J Cardiovasc Pharmacol 17 [Suppl 3]: S25-S33

22. Luheshi GN, Zar MA (1992) Effect of streptozotocin diabetes on motor and inhibitory transmission in rat anococcygeus. Can J Physiol Pharmacol 70: 1372-1378

23. Saenz de Tejada I, Goldstein I, Azadzoi K, Krane RJ, Cohen RA (1989) Impaired neurogenic and endothelium-mediated relaxation of penile smooth muscle from diabetic men with impotence. NEngl J Med 320: 1025-1030

24. LiCG, Rand MJ (1990) Nitric oxide and vasoactive intestinal polypeptide mediate non-adrenergic, non-cholinergic inhibitory transmission to smooth muscle of the rat gastric fundus. Eur J Pharmacol 191: 303-309

25. Kim N, Azadzoi KM, Goldstein I, Saenz de Tejada I (1991) A nitric oxide-like factor mediates nonadrenergic-noncholinergic neurogenic relaxation of penile corpus cavernosum smooth muscle. J Clin Invest 88: 112-118

26. Rajfer J, Aronson WJ, Bush PA, Dorey FJ, Ignarro LJ (1992) Nitric oxide as a mediator of relaxation of the corpus cavernosum in response to nonadrenergic, noncholinergic neurotransmission. N Engl J Med 326: 90-94

27. Waldman SA, Murad F (1987) Cyclic GMP synthesis and function. Pharmacol Rev 39: 163-196

28. Bucala R, Tracey KJ, Cerami A (1991) Advanced glycosylation products quench nitric oxide and mediate defective endothelium-dependent vasodilatation in experimental diabetes. J Clin Invest 87: 432-438

29. Vlassara H, Fuh H, Makita Z, Krungkrai S, Cerami A, Bucala R (1992) Exogenous advanced glycosylation end products induce complex vascular dysfunction in normal animals: a model for diabetic and aging complications. Proc Natl Acad Sci USA 89: 12043-12047 